\title{
Lipase-catalyzed kinetic resolution of 4-aryl- and 4-heteroarylbut-3-en-2-ols
}

\author{
Mariann Szigeti, ${ }^{a}$ Enikő R. Tőke, ${ }^{a}$ Maria C. Turóczi, ${ }^{b}$ Viviána Nagy, ${ }^{c}$ György Szakács, \\ and László Poppe ${ }^{\mathrm{a} *}$ \\ ${ }^{a}$ Budapest University of Technology and Economics, Department of Organic Chemistry and \\ Technology and Research Group for Alkaloid Chemistry, H-1111 Budapest, Szt. Gellért tér 4., \\ Hungary \\ b" Politehnica" University of Timisoara, Department of Applied Chemistry and Organic and \\ Natural Compounds Engineering, 300006 Timisoara, Piata Victoriei 2, Romania \\ ${ }^{c}$ Budapest University of Technology and Economics, Department of Applied Biotechnology and \\ Food Science, H-1111 Budapest, Szt. Gellért tér 4., Hungary \\ E-mail:poppe@mail.bme.hu
}

Dedicated to Professor Csaba Szántay on his $80^{\text {th }}$ birthday

\begin{abstract}
Several 4-aryl- and 4-heteroarylbut-3-en-2-ones [2a-c, bearing 4-phenyl-, 4-(furan-2-yl)- and 4-(1-benzyl-1H-indol-3yl)-substituents, respectively] were prepared by condensation reaction of acetone with the corresponding aldehydes (1a-c). Reduction of the ketones (2a,b) with $\mathrm{NaBH}_{4}$ resulted in the formation of the corresponding racemic secondary alcohols (rac-3a,b). On the other hand, reduction of the ketone bearing indole moiety (2c) gave an unstable product. The lipase-catalyzed enantiomer selective acetylation of the alcohols ( $r a c-3 a, b)$ by vinyl acetate has been investigated with a crude lipase from submerged fermentation (SmF) of a thermophilic fungus, with several crude enzyme preparations from solid state fermentation (SSF) of selected mesophilic fungi and with several commercially available lipases. The commercial and SmF lipases and the majority of SSF preparations exhibited high but usual enantiomer selectivities and resulted in the formation of $(R)$-acetates $[(R)-\mathbf{4 a}, \mathbf{b}]$ according to the Kazlauskas' rule. Several SSF preparations, however, behaved as selective anti-Kazlauskas catalysts.
\end{abstract}

Keywords: Allylic alcohols, enantiomer selectivity, lipase, solid state fermentation 


\section{Introduction}

There is an ever growing demand in the pharmaceutical and fine chemical industry for production of optically active intermediates. In this area, biocatalysis has expanded from a niche technology to a widely used manufacturing method. ${ }^{1}$ Biocatalysts - enzymes and whole-cell systems - as a result of their chiral nature are predominantly suited for production of optically pure stereoisomers. Several beneficial characteristics - broad substrate tolerance, no need for cofactors - make some hydrolases as useful biocatalysts for synthetic biotransformations. ${ }^{2}$ Among hydrolases, lipases (triacylglycerol carboxyl ester hydrolases, EC 3.1.1.3) proved to be the most versatile biocatalysts in stereoselective biotransformations such as kinetic resolutions, ${ }^{1-3}$ deracemisations and dynamic kinetic resolutions. ${ }^{4}$ Lipases are particularly suited for the kinetic resolution of secondary alcohols, since these enzymes exhibit high stability and enantioselectivity in organic solvents, and they are environmentally friendly. ${ }^{5}$ The commercial availability of a range of lipase preparations at low cost has also widely expanded their use as biocatalysts in organic chemistry.

Several studies on screening some thermophilic filamentous fungi in submerged fermentation (SmF) conditions, ${ }^{6}$ and some poorly studied mesophilic fungi in solid state fermentation (SSF) ${ }^{7}$ conditions for lipase/esterase activity resulted in biocatalysts exhibiting high enantiomer selectivity in synthetic biotransformations. The recent study of fungal SSF preparations acting on several typical secondary alcohols - such as 1-phenylethanol, 1-cyclohexylethanol and 1-(napth2-yl)ethanol - as model substrates indicated that SSF biocatalysts with lipase activity are applicable in kinetic resolutions of racemic secondary alcohols. ${ }^{7}$ As the gently dried SSF preparations do not require costly downstream processes, they can be considered as inexpensive, naturally immobilized biocatalysts. In the enzyme-catalyzed acetylation of the three selected racemic secondary alcohols ${ }^{7}$ several of the SSF biocatalysts exhibited high but usual enantioselectivities [formation of the $(R)$-acetates] according to the so-called "Kazlauskas' rule", ${ }^{8}$ whereas one strain (Mucor hiemalis) resulted in a selective "anti-Kazlauskas" biocatalyst by SSF. ${ }^{7}$

As the secondary alcohols in this study (with SSF biocatalysts) contained rigid (aromatic) or more flexible (cyclohexane) ring adjacent to the asymmetric carbon centre, ${ }^{7}$ one of our aims was to broaden the selection of the substrates for these SSF preparations by studying the kinetic resolution of allylic alcohols containing the rings at more remote position from the asymmetric center. The enantiomerically pure forms of such allylic alcohols (4-aryl- and 4-heteroarylsubstituted but-3-en-2-ols) and acetates are useful synthons which can be transformed to a wide range of more complex molecules. ${ }^{9}$ Different routes - such as kinetic resolutions by enzymatic acylation in apolar solvents ${ }^{10,11}$ or in ionic liquids ${ }^{12}$ - leading to both enantiomeric forms of chiral 4-aryl/heteroarylbut-3-en-2-ols have been reported. Other methods - such as ruthenium- ${ }^{13}$ or enzyme-catalyzed asymmetric reduction of the corresponding ketones ${ }^{14}$ or dynamic kinetic resolution of the racemic secondary alcohols including 4-phenyl- and 4-(furan-2-yl)but-3-en-2ols with lipases ${ }^{15}$ - however result in formation of just one particular enantiomeric form. In most 
cases, however, the availability of both enantiomers of the chiral starting materials in high enantiomer purity is essential. Therefore, we also considered to be important investigating the "anti-Kazlauskas" nature of the hydrolase preparations - which can lead to the opposite enantiomer in dynamic kinetic resolutions as the usual "Kazlauskas" enzymes - with the secondary allylic alcohol type substrates as well. We report here these aspects in kinetic resolution of racemic 4-aryl/heteroarylbut-3-en-2-ols with the best SSF hydrolase preparations, in comparison with commercial lipases.

\section{Results and Discussion}

From our previous screens of thermophilic $(\mathrm{SmF})^{6}$ and mesophilic filamentous fungi (SSF), ${ }^{7}$ several biocatalysts having comparable lipase activities and enantiomer selectivities to the widely used commercially available lipases were available for further screening. Within the strains of the SSF screen, ${ }^{7}$ a preparation (Mucor hiemalis) with the less usual anti-Kazlauskas selectivity was also found. Therefore we could study the kinetic resolution of several less characterized racemic allylic alcohols by a range of commercial and in-house prepared enzymes.

Syntheses of the racemic 4-aryl- and 4-heteroaryl-but-3-en-2-ols for this study seemed to be straightforward (Scheme 1).

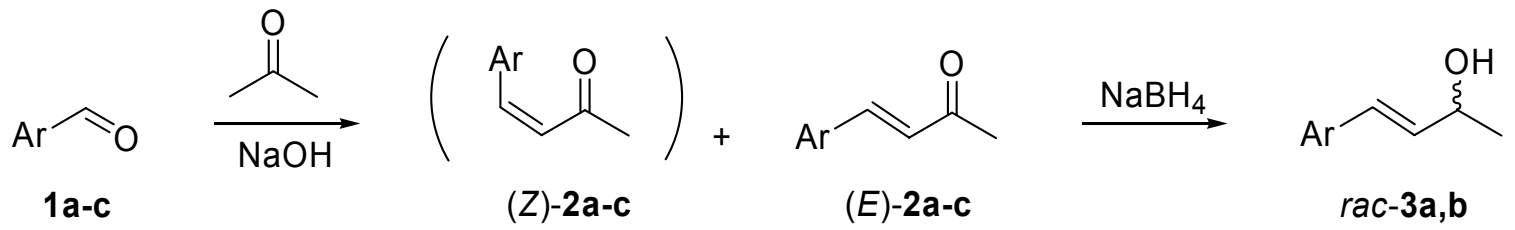

1-3 a

\section{Scheme 1}

Condensation of several typical aryl and heteroaryl aldehydes (benzaldehyde, 1a; furfural, 1b; 1-benzyl-1 $H$-indole-3-carbaldehyde 1c) using aqueous $\mathrm{NaOH}$ in excess acetone ${ }^{16}$ resulted in the formation of (3E)-4-aryl- and -heteroarylbut-3-en-2-ones containing various amounts of (3Z)isomers $[(E)$ - and $(Z)-\mathbf{2 a - c}]$. The $(Z)$-isomer content of the forming 4-phenylbut-3-en-2-one (2a) and 4-(furan-2-yl)but-3-en-2-one (2b) was about $30 \%$, whereas the (3E)-4-(1-benzyl-1H-indol3yl)but-3-en-2-one $[(E)-2 c]$ obtained after the usual work up including chromatography was virtually free of the other diastereomeric form. 
Reduction of the ketones proceeded smoothly. In the case of 4-phenylbut-3-en-2-one [(E)and (Z)-2a] the reaction was performed with $\mathrm{NaBH}_{4}$ in aqueous methanol to yield a hardly separable diastereomeric mixture of the secondary allylic alcohols [(E)- and (Z)-3a]. To avoid working with this mixture, pure alcohol $(E)$-3a was prepared from the commercially available $(E)$-2a under the same conditions. Reduction of the 4-(furan-2-yl)but-3-en-2-ones $[(E)$ - and $(Z)$ 2b] was also performed with $\mathrm{NaBH}_{4}$ in aqueous solvent system in the presence of $\mathrm{Ba}(\mathrm{OH})_{2}{ }^{17}$ leading to a separable mixture of the secondary allylic alcohols $[(E)$ - and $(Z)-3 \mathbf{b}]$. Reduction of the indole-containing ketone $[(E)-\mathbf{2 c}]$ under similar conditions resulted in the formation of a product (detected by TLC) which decomposed under the normal work up conditions.

Accordingly, the enzyme-catalyzed kinetic resolution of the racemic secondary allylic alcohols with a series of different biocatalysts was performed only with the racemic 4-phenyland 4-(furan-2-yl)-substituted but-3-en-2-ols [(E)-3a and (E)-3a, respectively] (Scheme 2).

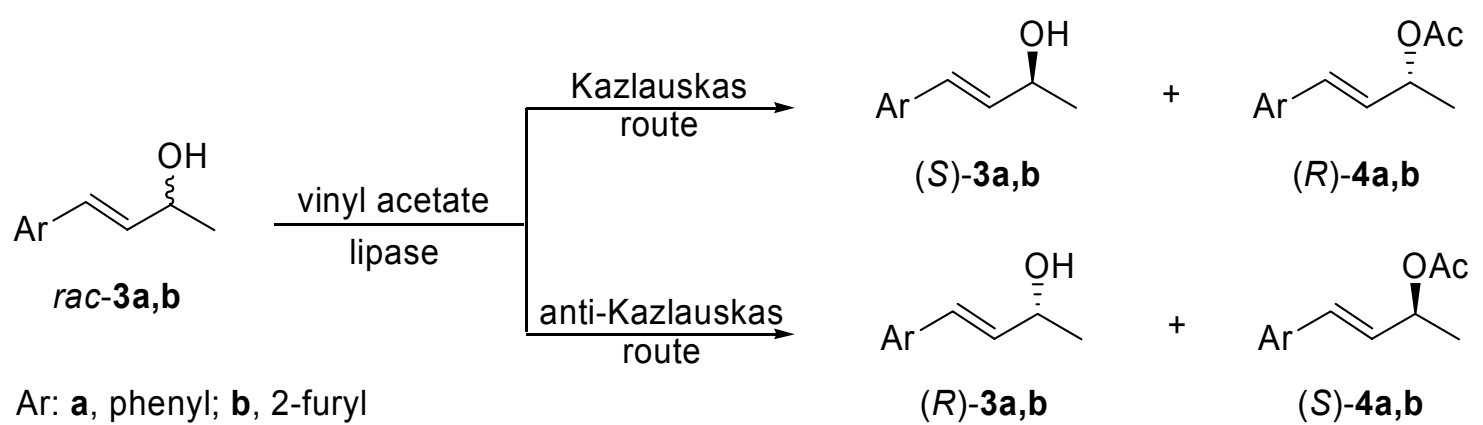

\section{Scheme 2}

Analysis of the reactions starting from racemic $(E)-\mathbf{2 a}$ by $\mathrm{GC}$ on chiral column revealed, that in our series there are effective biocatalysts with opposite enantiomeric preferences (Figure 1).

The enzyme-catalyzed kinetic resolution of racemic (3E)-4-phenylbut-3-en-2-ol (rac-3a) by enantiomer selective acylation using commercially available lipases is already known ${ }^{5,10}$ (Table 1, entries 2, 4-7). Dynamic kinetic resolution of the alcohol rac-3a with immobilized $P$. cepacia lipase leading to the virtually enantiopure $(R)$-acetate $[(R)-\mathbf{4 a}]$ is also described. ${ }^{15}$ 


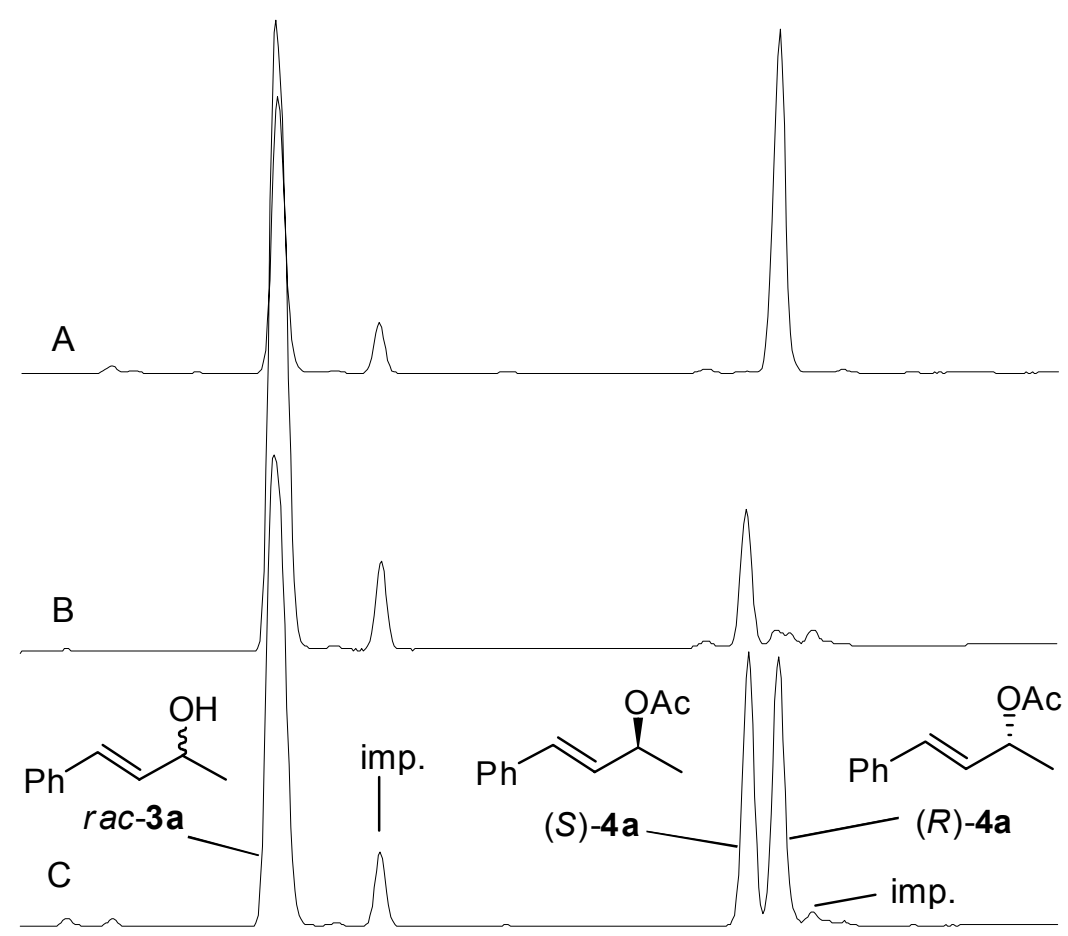

Figure 1. Analysis of the enzymatic acetylation of rac-3a by enantiomer selective GC. (A) lipase with Kazlauskas selectivity (sample BUTE 3b); (B) SSF preparation with anti-Kazlauskas selectivity (sample SSF-165); (C) mixture of racemic alcohol (rac-3a) and acetate (rac-4a).

In our screen, the majority of the already studied (Table 1, entries 2, 4-6) and several other (Table 1, entries 1,3) commercially available lipases were effective biocatalysts in this reaction and resulted in the formation of the $(R)$-acetate $[(R)-\mathbf{4 a}]$ in high enantiomeric purity $(95.6-99.5$ $\%$ ee) along with acceptable productivity (20 - $51 \%$ conversion within $24 \mathrm{~h})$. In several cases, the enantiomer selectivities $(E)$ determined for this series were slightly higher than those already reported (Table 1, entries 2, 4, 5).

The majority of the newly tested lipase preparations proved to be quite effective in the enzyme-catalyzed kinetic resolution of racemic (3E)-4-phenyl-but-3-en-2-ol (rac-3a) too. BUTE-3b and SSF-9 biocatalysts were found to be the best (Table 1, entries 8, 9), performing the reaction with even better enantiomer selectivity $(E)$ and productivity than that was observed with the best commercial lipases (Table 1, entries 1,2). 
Table 1. Kinetic resolution of racemic (3E)-4-phenylbut-3-en-2-ol (rac-3a) by lipases

\begin{tabular}{|c|c|c|c|c|c|c|c|}
\hline \multirow[t]{2}{*}{ Entry } & \multirow[t]{2}{*}{ Biocatalyst $^{\mathrm{a}}$} & \multirow{2}{*}{$\begin{array}{c}\text { Time } \\
\text { (h) }\end{array}$} & \multirow{2}{*}{$\begin{array}{c}\text { Conv. }^{\mathrm{b}} \\
(\%)\end{array}$} & \multicolumn{2}{|c|}{$4 \mathbf{a}$} & \multirow[t]{2}{*}{$E^{\mathrm{c}}$} & \multirow[t]{2}{*}{$E^{\text {lit. }}$} \\
\hline & & & & Config. & $e e^{\mathrm{b}}(\%)$ & & \\
\hline 1 & Lipozyme TL IM & 24 & 35 & $R$ & 99.5 & $» 200$ & - \\
\hline 2 & PPL & 24 & 31 & $R$ & 99.5 & $» 200$ & $>100^{5}$ \\
\hline 3 & P. fluorescens lipase & 24 & 22 & $R$ & 99.4 & $>200$ & - \\
\hline 4 & Lipase PS & 24 & 48 & $R$ & 98.3 & $>200$ & $61^{10}$ \\
\hline 5 & CaLB & 4 & 51 & $R$ & 95.6 & $>100$ & $93^{10}$ \\
\hline 6 & Lipase AK & 4 & 45 & $R$ & 97.7 & $>100$ & $284^{10}$ \\
\hline 7 & CCL & 192 & 5 & $R$ & 65.5 & 5 & $6^{10}$ \\
\hline 8 & BUTE-3b & 4 & 49 & $R$ & 99.0 & $» 200$ & - \\
\hline 9 & SSF-9 & 24 & 47 & $R$ & 99.0 & $» 200$ & - \\
\hline 10 & SSF-23 & 24 & 43 & $R$ & 98.9 & $>200$ & - \\
\hline 11 & SSF-65 & 24 & 51 & $R$ & 87.9 & 52 & - \\
\hline 12 & SSF-101 & 72 & 36 & $R$ & 93.6 & 51 & - \\
\hline 13 & SSF-130 & 192 & 8 & $S$ & 74.3 & 7 & - \\
\hline 14 & SSF-165 & 192 & 12 & $S$ & 73.8 & 7 & - \\
\hline
\end{tabular}

${ }^{\mathrm{a}}$ For details on the biocatalysts and reaction conditions, see the Experimental section. ${ }^{\mathrm{b}}$ The conversion and the ee of $\mathbf{4 a}$ were determined by GC on Hydrodex- $\beta$-PM column. ${ }^{c}$ Enantiomer selectivity $(E)$ was calculated from conversion and $e e_{4 a} \cdot{ }^{18}$ Due to sensitivity to experimental errors, $E$ values calculated in the 100-300 range are reported as $>100$, values in the 300-500 range are reported as $>200$ and values calculated above 500 are given as $» 200$.

These data support the former observations that many preparations of filamentous fungi exhibiting lipase/esterase activity produced by submerged $(\mathrm{SmF})^{6}$ or solid state fermentation $(\mathrm{SSF})^{7}$ are useful biocatalysts in stereoselective organic reactions. In the kinetic resolution of the allylic alcohol rac-3a, two SSF preparations exhibited better "anti-Kazlauskas" selectivities ( $E \sim 7$, Table 1, entry 13: Mucor hiemalis ATCC 26035, entry 14: Rhizomucor pusillus WFPL 267 A) than the already known anti-Kazlauskas biocatalyst (SSF-63, Mucor hiemalis NRRL 13.009, previously tested on racemic 1-phenylethanol ${ }^{7}$ ). Although the selectivities and productivities of these biocatalysts were only moderate, they represent a useful type of complementary selectivity which was precedented in protease-catalyzed reactions so far. ${ }^{15 \mathrm{c}}$

The enantiomer selective acylation of racemic (3E)-4-(furan-2-yl)but-3-en-2-ol (rac-3b) using lipases (Table 2) has not been characterized in detail, as no data on the lipase-catalyzed kinetic resolution of this substrate was found. However, dynamic kinetic resolution of rac-3b with immobilized $P$. cepacia lipase exhibiting the usual "Kazlauskas" selectivity is already known. ${ }^{15}$ 
Table 2. Kinetic resolution of racemic (3E)-4-(furan-2-yl)but-3-en-2-ol ( $r a c-3 b)$ by lipases

\begin{tabular}{|c|c|c|c|c|c|c|c|}
\hline \multirow[t]{2}{*}{ Entry } & \multirow[t]{2}{*}{ Biocatalyst $^{\mathrm{a}}$} & \multirow{2}{*}{$\begin{array}{l}\text { Time } \\
\text { (h) }\end{array}$} & \multirow{2}{*}{$\begin{array}{c}\text { Conv. } \\
(\%)\end{array}$} & \multirow{2}{*}{$\begin{array}{c}\mathbf{3 b} \\
e e^{(\%)^{b}}\end{array}$} & \multicolumn{2}{|c|}{$4 b$} & \multirow[t]{2}{*}{$E^{\mathrm{c}}$} \\
\hline & & & & & Config. & $e e(\%)^{b}$ & \\
\hline 1 & P. fluorescens lipase & 72 & 48 & 99.2 & $R$ & 99.6 & $» 200$ \\
\hline 2 & PPL & 72 & 50 & 99.6 & $R$ & 99.2 & $» 200$ \\
\hline 3 & Lipozyme TL IM & 72 & 52 & 99.5 & $R$ & 96.1 & $>200$ \\
\hline 4 & Lipase PS & 72 & 52 & 97.7 & $R$ & 93.8 & $>100$ \\
\hline 5 & Lipase AK & 4 & 53 & 83.5 & $R$ & 87.4 & 39 \\
\hline 6 & PLE & 192 & 15 & 14.8 & $R$ & 80.9 & 11 \\
\hline 7 & CaLB & 4 & 26 & 9 & $R$ & 75.0 & 9 \\
\hline 8 & CCL & 192 & 5 & 3.7 & $R$ & 64.3 & 5 \\
\hline 9 & SSF-23 & 72 & 48 & 90.8 & $R$ & 98.2 & $>200$ \\
\hline 10 & BUTE-3b & 4 & 51 & 99.0 & $R$ & 91.2 & $>100$ \\
\hline 11 & SSF-9 & 72 & 51 & 99.6 & $R$ & 95.8 & $>100$ \\
\hline 12 & SSF-101 & 72 & 33 & 40.5 & $R$ & 93.8 & 46 \\
\hline 13 & SSF-65 & 72 & 59 & 99.4 & $R$ & 66.9 & 28 \\
\hline 14 & SSF-130 & 192 & 3 & 0.1 & $S$ & 75.4 & 7 \\
\hline 15 & SSF-165 & 192 & 28 & 19.8 & $S$ & 62.6 & 5 \\
\hline
\end{tabular}

${ }^{\mathrm{a}}$ For details on the biocatalysts and reaction conditions, see the Experimental section. ${ }^{\mathrm{b}}$ The conversion and the ee values of $\mathbf{3 b}$ and $\mathbf{4 b}$ were determined by GC on Hydrodex- $\beta$-PM column. ${ }^{c}$ Enantiomer selectivity $(E)$ was calculated from conversion and $e e_{\mathbf{4 b}}{ }^{18}$ (and confirmed by independent calculation from $e e_{3 \mathbf{b}}$ and $\left.e e_{\mathbf{4}}{ }^{19}\right)$. Due to sensitivity to experimental errors, $E$ values calculated in the 100-300 range are reported as $>100$, values in the 300-500 range are reported as $>200$ and values calculated above 500 are given as $» 200$.

Interestingly, replacement of the phenyl (in $r a c-3 a)$ to a similarly bulky but more polar furan2-yl moiety (in rac-3b) at position 4 of the racemic secondary allylic alcohol resulted in significant decrease of the enantiomer selectivity $(E)$ of several commercial lipases such as Lipase AK and CaLB (from $E>100$ in Table 1, entries 6 and 5 to $E=39$ and $E=9$ in Table 2, entries 5 and 7; respectively).

This drop in enantiomer selectivity $(E)$ in the kinetic resolution of the furyl-substituted alcohol ( $r a c-3 b)$ in comparison with $E$ value for the phenyl-substituted alcohol ( $r a c-3 b)$ was also experienced with the biocatalysts of filamentous fungal origin prepared by us (Table 2, entries 913 vs. Table 1, entries 8-12; respectively). The most significant decrease of $E$ has been detected in the reactions catalyzed by BUTE-3b and SSF-9 preparations (from $E » 200$ in Table 1, entries 8 and 9 to $E>100$ and $E>200$ in Table 2, entries 10 and 9; respectively).

The fungal SSF preparations exhibiting "anti-Kazlauskas" selectivity with the phenylsubstituted substrate (rac-3a) retained their sense of enantiomeric preference in the biotransformation of the furan-2-yl-substituted alcohol ( $\mathrm{rac}-\mathbf{3 b})$ as well. Thus, they also acted as 
"anti-Kazlauskas" biocatalysts resulting in the formation of the $(S)$-acetate $[(S)-4 \mathbf{b}]$ with moderate enantiomer selectivities (Table 2, entry 14: Mucor hiemalis ATCC 26035, E $=7$ and Table 2, entry 15: Rhizomucor pusillus WFPL $267 \mathrm{~A}, E=5)$.

\section{Conclusions}

It was demonstrated that kinetic resolution of racemic 4-aryl and 4-heteroaryl-substituted but-3-

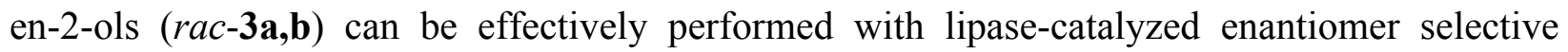
acetylation by vinyl acetate. In addition to the commercially available lipases, several crude lipase preparations from submerged $(\mathrm{SmF})$ or solid state (SSF) fermentations of filamentous fungi proved to be useful biocatalysts in this kinetic resolution. Whereas all of the commercial lipases and most of the fungal preparations exhibited high but usual "Kazlauskas-type" enantiomer selectivities with the investigated racemic secondary allylic alcohols (rac-3a,b), several of our SSF preparations turned out to be "anti-Kazlauskas" biocatalysts.

\section{Experimental Section}

General Procedures. NMR spectra were recorded on a Bruker-500 spectrometer (500 $\mathrm{MHz}$ for ${ }^{1} \mathrm{H}$ and $125 \mathrm{MHz}$ for ${ }^{13} \mathrm{C}$; TMS; ppm on $\delta$ scale) in $\mathrm{CDCl}_{3}$ if not stated otherwise. GC analyses were carried out on HP 5890 instrument equipped with FID detector using $\mathrm{H}_{2}$ as carrier gas (injector: $250^{\circ} \mathrm{C}$, detector $250^{\circ} \mathrm{C}$, head pressure: 26 psi, 1:80 split ratio) on Hydrodex- $\beta$-PM (50 $\mathrm{m} \times 0.25 \mathrm{~mm} \times 0.25 \mu \mathrm{m}$ film, Macherey-Nagel, No.: 723370-50) column. TLC was carried out on Kieselgel $60 \mathrm{~F}_{254}$ (Merck) sheets. Spots were visualized by treatment with 5\% ethanolic phosphomolybdic acid solution and heating of the dried plates.

Chemicals and enzymes. Benzaldehyde (1a), furfural (1b) and trans-4-phenyl-3-but-2-one (2a) were products of Aldrich. All further chemicals and solvents were of analytical grade or higher and purchased from Sigma-Aldrich, Hungary Ltd. 1-Benzyl-1H-indole-3-carbaldehyde (1c) was prepared as described previously. ${ }^{20}$

Commercially available lipases for this study were: Lipozyme TL IM (Novozymes; immobilized lipase from Thermomyces lanuginosus); Lipase (B lipase) from Candida antarctica, CaLB (Sigma, L 4777; immobilized on acrylic resin); Lipase from porcine pancreas, Type II, PPL (Sigma, L 3126); Lipase from Pseudomonas fluorescens (Fluka, 71548); Lipase from Candida cylindracae, CCL (Fluka, 62316); Lipase PS from Pseudomonas cepacia, Amano (Aldrich, 534641); Lipase AK from Pseudomonas fluorescens, Amano (Aldrich, 534730).

BUTE and SSF enzymes were obtained from thermophilic and mesophilic fungi cultivated under submerged $^{6}$ and solid state fermentation, ${ }^{7}$ respectively. BUTE-3b: Malbranchea pulchella var. sulfurea; SSF-9: Gliocladium catenulatum NRRL 1093; SSF-23: Gliocladium roseum NRRL 
1085; SSF-65: Chaetomium globosum OKI 270; SSF-101: Chaetomium elatum UAMH 2672; SSF-130: Mucor hiemalis ATCC 26035; SSF-165: Rhizomucor pusillus WFPL 267 A.

Preparation of (3E)-4-heteroarylbut-3-en-2-ones $(\mathbf{2 b}, \mathbf{c}) .{ }^{16}$ To a solution of carbaldehyde (1b or 1 c, $95 \mathrm{mmol})$ in acetone $(260 \mathrm{mmol})$ and water $(10 \mathrm{~mL})$ was added dropwise $10 \%$ sodium hydroxide solution $(2.5 \mathrm{~mL})$ with keeping the temperature under $30^{\circ} \mathrm{C}$. After stirring at room temperature for $4 \mathrm{~h}$, the resulting mixture was acidified $(\mathrm{pH} \sim 4)$ with $5 \% \mathrm{HCl}$ solution. After evaporation off the acetone by vacuum rotary evaporator, the residual aqueous layer was extracted with toluene $(3 \times 20 \mathrm{~mL})$ and the combined organic layers were washed with water $(2$ $\times 20 \mathrm{~mL}$ ) and dried over $\mathrm{Na}_{2} \mathrm{SO}_{4}$. The solvent was evaporated and the product was purified by column chromatography (silica gel, hexane-ethyl acetate 10:1).

(3E)- and (3Z)-4-(2-Furyl)but-3-en-2-one [(E)-2b+(Z)-2b]. Yield: $81 \%$. Anal. Calcd. $\mathrm{C}_{8} \mathrm{H}_{8} \mathrm{O}_{2}$ : C, 70.57; H, 5.92. Found: C, 70.61; H, 5.88. ${ }^{1} \mathrm{H}-\mathrm{NMR}: 2.24$ (s, 3H), 6.40 (dd, $J=1.5 \mathrm{~Hz}, J=3.5$ $\mathrm{Hz}, 0.7 \mathrm{H}), 6.42(\mathrm{dd}, J=1.5 \mathrm{~Hz}, J=3.5 \mathrm{~Hz}, 0.3 \mathrm{H}), 6.53(\mathrm{~d}, J=15.7 \mathrm{~Hz}, 0.7 \mathrm{H}), 6.58(\mathrm{~d}, J=3.5 \mathrm{~Hz}$, $0.7 \mathrm{H}), 6.61(\mathrm{~d}, J=3.5 \mathrm{~Hz}, 0.3 \mathrm{H}), 6.83(\mathrm{~d}, J=15.7 \mathrm{~Hz}, 0.3 \mathrm{H}), 7.19(\mathrm{~d}, J=15.7 \mathrm{~Hz}, 0.7 \mathrm{H}), 7.39$ (d, $J=15.7 \mathrm{~Hz}, 0.3 \mathrm{H}), 7.42(\mathrm{~d}, J=1.5 \mathrm{~Hz}, 0.7 \mathrm{H}), 7.43(\mathrm{~d}, J=1.5 \mathrm{~Hz}, 0.3 \mathrm{H}) \cdot{ }^{13} \mathrm{C}-\mathrm{NMR}$ (signals of the minor isomer (Z)-2b are in brackets): 27.97, 112.68 (112.78), 115.76 (116.01), 124.45 (123.34), 129.34 (129.55), 145.15 (145.08), 151.05 (151.66), 197.92 (188.20). NMR data of the major isomer $(E)$-2b agreed with the reported spectra. ${ }^{21}$

(3E)-4-(1-Benzyl-1H-indol-3yl)but-3-en-2-one (2c). Yield: $65 \%$. Anal. Calcd. $\mathrm{C}_{19} \mathrm{H}_{17} \mathrm{NO}$ : $\mathrm{C}$, 82.88; H, 6.22; N, 5.09. Found: C, 82.95; H, 6.27; N, 5.16. ${ }^{1} \mathrm{H}-\mathrm{NMR}: 2.40$ (s, 3H), 5.35 (s, 2H), $6.81(\mathrm{~d}, 1 \mathrm{H}, J=16.1 \mathrm{~Hz}), 7.18(\mathrm{~d}, 2 \mathrm{H}), 7.30(\mathrm{~m}, 2 \mathrm{H}), 7.35(\mathrm{~m}, 1 \mathrm{H}), 7.37(\mathrm{~m}, 3 \mathrm{H}), 7.47(\mathrm{~s}, 1 \mathrm{H})$, $7.79(\mathrm{~d}, 1 \mathrm{H}, J=16.1 \mathrm{~Hz}), 7.98(\mathrm{~m}, 1 \mathrm{H}) .{ }^{13} \mathrm{C}-\mathrm{NMR}: 27.21,50.45,110.53,112.62,120.65,121.61$, $122.88,123.26,126.27,126.98,128.10,128.96,132.86,135.97,137.00,137.75,198.48$.

\section{Reduction of ketones (2a-c) to racemic alcohols (rac-3a,b)}

Method A. To a solution of (3E)-4-phenylbut-3-en-2-one (2a, $1.3 \mathrm{~g}, 8.9 \mathrm{mmol})$ in methanol (30 $\mathrm{mL})$ was added dropwise a solution of $\mathrm{NaBH}_{4}(0.34 \mathrm{~g}, 8.9 \mathrm{mmol})$ in methanol $(15 \mathrm{~mL})$ over 15 min (under $45{ }^{\circ} \mathrm{C}$ ). After stirring the resulting mixture at room temperature overnight, the methanol was distilled off and the residue was taken in ethyl acetate $(40 \mathrm{~mL})$, washed with $5 \%$ $\mathrm{HCl}(3 \times 20 \mathrm{~mL})$, saturated $\mathrm{NaHCO}_{3}$ solution $(3 \times 20 \mathrm{~mL})$, brine $(2 \times 20 \mathrm{~mL})$ and dried over $\mathrm{Na}_{2} \mathrm{SO}_{4}$. The solvent was evaporated and the product was purified by column chromatography (silica gel, toluene - ethyl acetate $20: 1$ ) to give $r a c-3 a$ as colorless oil.

(3E)-4-Phenylbut-3-en-2-ol (rac-3a). Yield: 0.84 g, 85 \%. Anal. Calcd. $\mathrm{C}_{10} \mathrm{H}_{12} \mathrm{O}$ : C, 81.04; H, 8.16. Found: $\mathrm{C}, 81.01 ; \mathrm{H}, 8.09$. GC $\left(50-190{ }^{\circ} \mathrm{C}, 5{ }^{\circ} \mathrm{C} \mathrm{min}{ }^{-1}\right), t_{\mathrm{R}}(\mathrm{min}): 23.73$, rac-3a. ${ }^{1} \mathrm{H}-\mathrm{NMR}$ : $1.37(\mathrm{~d}, 3 \mathrm{H}), 2.59(\mathrm{br} \mathrm{s}, 1 \mathrm{H}), 4.52(\mathrm{~m}, 1 \mathrm{H}), 6.57(\mathrm{~m}, 1 \mathrm{H}), 6.73(\mathrm{~d}, 1 \mathrm{H}), 7.3(\mathrm{~m}, 5 \mathrm{H}) .{ }^{13} \mathrm{C}-\mathrm{NMR}$ : $23.61,68.96,126.58,127.72,128.70,129.44,133.71,136.86$. NMR data agreed with the reported spectra. ${ }^{11}$

Method B. Attempted preparations of (3E)-4-(furan-2-yl)but-3-en-2-ol (rac-3b) and (3E)-4(1-benzyl-1H-indol-3-yl)but-3-en-2-ol ( $\mathrm{rac}-3 \mathrm{c})(100 \mathrm{mmol})$ were carried out according to the 
method recorded in the literature ${ }^{17}$ using $\mathrm{Ba}(\mathrm{OH})_{2}$ in aqueous solvent system.

(3E)-4-(Furan-2-yl)but-3-en-2-ol (rac-3b). Yield: 55 \% (chromatography on silica gel, tolueneEtOAc 30:1). Anal. Calcd. $\mathrm{C}_{8} \mathrm{H}_{10} \mathrm{O}_{2}$ : C, 69.54; H, 7.30. Found: C, 69.52; H, 7.22. GC (80-160 $\left.{ }^{\circ} \mathrm{C}, 5{ }^{\circ} \mathrm{C} \mathrm{min}{ }^{-1}\right), t_{\mathrm{R}}(\min ): 13.99,(R)-3 \mathbf{b} ; 14.09,(S)-3 \mathbf{b} .{ }^{1} \mathrm{H}-\mathrm{NMR}$ (DMSO-d 6 ): ${ }^{1} \mathrm{H}-\mathrm{NMR}: 1.18(\mathrm{~d}$, $J=6.6 \mathrm{~Hz}, 3 \mathrm{H}), 4.28(\mathrm{~m}, 1 \mathrm{H}), 4.88($ br s, $1 \mathrm{H}), 6.12(\mathrm{dd}, J=16.0 \mathrm{~Hz}, J=5.5 \mathrm{~Hz}, 1 \mathrm{H}), 6.36(\mathrm{~d}, J=$ $3.5 \mathrm{~Hz}, 1 \mathrm{H}), 6.38(\mathrm{dd}, J=16.0 \mathrm{~Hz}, J=1.3 \mathrm{~Hz}, 1 \mathrm{H}), 6.44(\mathrm{dd}, J=3.5 \mathrm{~Hz}, J=1.9 \mathrm{~Hz}, 1 \mathrm{H}), 7.56(\mathrm{~d}$, $J=1.9 \mathrm{~Hz}, 1 \mathrm{H}) .{ }^{13} \mathrm{C}-\mathrm{NMR}\left(\mathrm{DMSO}_{\mathrm{d}}\right.$ ): 23.61, 66.00, 107.43, 111.41, 116.02, 133.95, 142.12 , 152.24. NMR data agreed with the reported spectra. ${ }^{22}$

(3E)-4-(1-Benzyl-1H-indol-3-yl)but-3-en-2-ol (rac-3c). A product was observed on TLC but proved to be unstable during the workup process and attempted column chromatography.

\section{Acetylation of racemic alcohols (rac-3a-b)}

Method A (chemical acetylation). To the racemic alcohol (rac-3a,b) $(0.67 \mathrm{mmol})$ in triethylamine $(10 \mathrm{~mL})$, acetic anhydride $(137 \mathrm{mg}, 1.34 \mathrm{mmol})$ was added and the resulting mixture was refluxed for $1 \mathrm{~h}$. After cooling, the reaction mixture was diluted with ethyl acetate $(20 \mathrm{~mL})$ and washed with water $(2 \times 10 \mathrm{~mL}), 5 \% \mathrm{HCl}(2 \times 10 \mathrm{~mL})$, saturated $\mathrm{NaHCO}_{3}$ solution $(2 \times 10 \mathrm{~mL})$ and brine $(10 \mathrm{~mL})$. The organic layer was dried over $\mathrm{Na}_{2} \mathrm{SO}_{4}$ and concentrated under reduced pressure. The residue was purified by column chromatography (silica gel, hexaneethyl acetate $20: 1)$.

(3E)-4-Phenylbut-3-en-2-yl acetate (rac-4a). Yield: $90 \%$. Anal. Calcd. $\mathrm{C}_{12} \mathrm{H}_{14} \mathrm{O}_{2}$ : C, 75.76; $\mathrm{H}$, 7.42. Found: $\mathrm{C}, 75.74 ; \mathrm{H}, 7.37$. $\mathrm{GC}\left(50-190{ }^{\circ} \mathrm{C}, 5^{\circ} \mathrm{C} \mathrm{min}{ }^{-1}\right), t_{\mathrm{R}}(\mathrm{min}): 25.09,(S)-4 \mathrm{a} ; 25.17,(R)-$ 4a. ${ }^{1} \mathrm{H}-\mathrm{NMR}: 1.44(\mathrm{~d}, 3 \mathrm{H}), 2.10(\mathrm{~s}, 3 \mathrm{H}), 5.56(\mathrm{~m}, 1 \mathrm{H}), 6.22(\mathrm{dd}, 1 \mathrm{H}), 6.63(\mathrm{~d}, 1 \mathrm{H}), 7.25-7.42(\mathrm{~m}$, 5H). ${ }^{13}$ C-NMR: 20.31, 21.32, 70.95, 126.49, 127.84, 128.51, 128.75, 131.49, 136.28, 170.31. NMR data agreed with the reported spectra. ${ }^{10}$

(3E)-4-(Furan-2-yl)but-3-en-2-yl acetate (rac-4b). Yield, $85 \%$. Anal. Calcd. $\mathrm{C}_{10} \mathrm{H}_{12} \mathrm{O}_{3}$ : C, 66.65; H, 6.71. Found: C, 66.63; H, 6.64. GC $\left(80-160{ }^{\circ} \mathrm{C}, 5{ }^{\circ} \mathrm{C} \mathrm{min}{ }^{-1}\right), t_{\mathrm{R}}(\mathrm{min}): 15.34,(S)-4 \mathbf{b}$; 15.48, (R)-4a. ${ }^{1} \mathrm{H}-\mathrm{NMR}: 1.34$ (d, J=6.3 Hz, 3H), 2.07 (s, 3H), 5.45 (m, 1H), 6.25-6.35 (m, 4H), $7.28(\mathrm{~d}, \mathrm{I}=1.9 \mathrm{~Hz}, 1 \mathrm{H}) .{ }^{13} \mathrm{C}-\mathrm{NMR}: 20.18,21.15,70.48,108.65,111.22,119.76,127.41,142.10$, 152.04, 170.11. NMR data agreed with the reported spectra. ${ }^{17}$

Method B (Enzymatic acetylation). The enzymes listed in Table 1 and Table 2 (50 mg) and vinyl acetate $(100 \mu \mathrm{l})$ were added to solutions of $\mathrm{rac}-\mathbf{3 a}$ and $\mathrm{rac}-\mathbf{3 b}(50 \mathrm{mg})$ in hexane-THF 1:1 $(2 \mathrm{ml})$. The resulting suspensions were shaken at $1000 \mathrm{rpm}$ at room temperature in sealed glass vials for time indicated in Table 1 and Table 2 NMR spectra of the optically active products were identical to the racemic compounds reported above.

\section{Acknowledgements}

L. P. thanks the financial support from Hungarian OTKA Foundation (T-048854). 


\section{References}

1. (a) Faber, K. Biotransformations in Organic Chemistry, $4^{\text {th }}$ Edn.; Springer: Berlin, 2004. (b) Rehm, H.-J.; Reed, G.; Pühler, A.; Stadler, D.; Kelly, R. Biotechnology: Biotransformations I and II, Vols. $8 a$ and 8b, $2^{\text {nd }}$ Edn.; Wiley-VCH: Weinheim, 1998. (c) Poppe, L.; Novák, L. Selective Biocatalysis: A Synthetic Approach, VCH: Weinheim-New York, 1992.

2. Bornschauer, U. T.; Kazlauskas, R. J. Hydrolases in Organic Synthesis: Regio- and Stereoselective Biotransformations, Wiley-VCH: Weinheim-New York, 2006.

3. Ghanem, A.; Aboul-Enein, H. Y. Chirality 2005, 17, 1.

4. Turner, N. J. Curr. Opin. Chem. Biol. 2004, 8, 114.

5. Morgan, B.; Oehlschlager, A. C.; Stokes, T. M. J. Org. Chem. 1992, 57, 3231.

6. Bódai, V.; Peredi, R.; Bálint, J.; Egri, G., Novák, L.; Szakács, G., Poppe, L. Adv. Synth. Catal. 2003, 345, 811.

7. Nagy, V.; Tőke, E.R.; Keong, L.Ch.; Szatzker, G.; Ibrahim, D.; Che Omar, I.; Szakács, G.; Poppe, L. J. Mol. Catal. B: Enzymatic 2006, 39, 141.

8. Kazlauskas, R. J. ; Weissfloch, A. N. E.; Rappaport, A. T.; Cuccia, L. A. J. Org. Chem. 1991, 56, 2656.

9. (a) Johnson, R. A.; Sharpless, K. B. In ComprehensiVe Organic Synthesis; Trost, B. M., Ed.; Pergamon: Oxford, 1991; Vol. 7, p 389. (b) Jonson, R. A.; Sharpless, K. B. In Catalytic Asymmetric Synthesis; Ojima, I., Ed.; VCH: New York, 1993; Chapter 4. (c) Heck, R. F. Palladium Reagents in Organic Synthesis; Academic: London, 1985; Chapter 5. (d) Tsuji, J. Palladium Reagents and Catalysts; John Wiley \& Sons: Chichester, 1997; Chapter 4.

10. Ghanem, A.; Schurig, V. Tetrahedron: Asymmetry 2003, 14, 57.

11. Kamal, A.; Sandbhor, M.; Shaik, A. A.; Sravanthi, V. Tetrahedron: Asymmetry 2003, 14, 2839.

12. Tsukada, Y.; Iwamoto, K.; Furutani, H.; Matsushita, Y.; Abe, Y.; Matsumoto, K.; Monda, K.; Hayase, S.; Kawatsura, M.; Itoh, T. Tetrahedron Letters 2006, 47, 1801.

13. Noyori, R.; Ohkuma, T. Angew. Chem., Int. Ed. 2001, 40, 40.

14. Hage, A.; Petra, D.; Field, J.; Schipper, D.; Wijnberg, J.; Kamer, P.; Reek, J.; Leeuwen, P.; Wever, R.; Shoemaker, H. Tetrahedron: Asymmetry 2001, 12, 1025.

15. (a) Choi, Y. K.; Suh, J. H.; Lee, D. ; Lim, I. T.; Jung, J. Y.; Kim, M.-J. J. Org. Chem. 1999, 64, 8423. (b) Lee, D.; Huh, E. A.; Kim, M.-J.; Jung, H. M.; Koh, J. H.; Park, J. Organic Letters 2000, 2, 2377. (c) Kim, M.-J.; Park, J. W.; Chung, Y. I.; Choi, J. H.; Lee, H. K.; Choi, Y. K.; Kim, D. PCT Int. Appl. WO 2005009935, 2005: Chem. Abstr. 2005, 142, 197677.

16. Nishiyama, Y.; Makino, Y., Hamanaka, S.; Ogawa, A., Sonoda, N. Bull. Chem. Soc. Jpn. 1989, 62, 1682.

17. Dell, C. P.; Smith, E. H. J. Chem. Soc. Perkin Trans. 1 1985, 747.

18. Chen, C. S.; Fujimoto, Y.; Girdaukas, G.; Sih, C. J. J. Am. Chem. Soc. 1982, 104, 7294.

19. Rakels, J. L. L.; Straathof, A. J. J.; Heijnen, J. J. Enzyme Microb. Technol. 1993, 15, 1051. 
20. Kurihara, T.; Fujimoto, T.; Harusawa, S.; Yoneda, R. Synthesis 1987, 396.

21. Hayakawa, K.; Yodo, M.; Ohsuki, S.; Kanematsu, K. J. Am. Chem. Soc. 1984, 106, 6735.

22. Pascal, Y.; Morizur, J. P.; Wiemann, J. Bull. Soc. Chim. France 1965, 2211. 